\title{
The Leader as Chief Strategist
}

\author{
Thomas G. Marx, Ph.D. \\ Lawrence Technological University \\ 21000 West Ten Mile Road \\ Southfield, MI 48075-1058 \\ Ph.: (248) 204-3081 \\ Fax: (248) 204-3099 \\ e-mail: tmarx@1tu.edu
}

\begin{abstract}
Modern academic links between leadership and strategy were forged in the early 1960s with the heightened application of strategy to business planning. These links were soon dissolved by the strategy consultants who came to dominate the field of business strategy in the mid-1960s. The consultants dismissed the role of leadership in strategic planning in favor of objective analyses of the external environment that eliminated any need for leadership skills, judgment, values, or intuition. Failures to implement strategy in the 1980s led to limited roles for leaders in implementing strategies they had no role in creating, but the gulf between leadership and strategy has steadily widened.

This paper traces the consequences of this widening gulf for teaching leadership and strategy in the classroom. It explores how an integrated approach to teaching leadership and strategy would better prepare today's students for the challenges they will face as future business leaders.
\end{abstract}

\section{Introduction}

In her recent book, The Strategist: Be the Leader Your Business Needs, Cynthia Montgomery writes: "Leadership and strategy are inseparable" (2012, p.12). But, "These two aspects of what leaders do, once tightly linked, have grown apart" (2012, p.12). She argues that “.... strategy and leadership must be reunited at the highest level of an organization. All leaders. ... must accept and own strategy as the heart of their responsibilities" (2012, p.13).

Leadership and (military) strategy have impressive lineages that date back thousands of years to common origins, e.g., Sun Tzu, The Art of War (500 BCE). However, modern academic links between leadership and strategy were forged much later in the seminal works of Barnard (1938), Drucker (1946), Ansoff (1965), Andrews (1971), and Mintzberg (1973). Unfortunately, these links were largely dissolved by the strategy consultants who came to dominate the field in the mid-1960s. The consultants dismissed the role of leadership in strategic planning in favor of formulistic approaches to strategy that eliminated any need for leadership skills, judgment, values, or intuition. Failures to implement strategy in the 1980s led to limited roles for leaders in 
implementing strategies they had no role in creating, but the gulf between leadership and strategy steadily widened over the proceeding decades.

This paper sketches the main theoretical paths along which strategy and leadership developed; explores why they diverged in the 1960s; and the consequences of their diversion for teaching leadership and strategy in the classroom. Most importantly, the paper advances an integrated theoretical approach to teaching leadership and strategy that would better prepare today's students for the challenges they will face as future business leaders.

\section{Strategy}

Strategy is as old as human conflict. It has been at the center of military thought and action for thousands of years (Hart, 1967; Musashi, 1645; Sun Tzu, 500 BCE; and von Clausewitz, 1832), but its application to business is very recent, with companies not undertaking strategic planning before the 1960s (Kiechel, 2010). Companies budgeted, made assumptions about the external environment, conducted gap analyses (forecasts vs. actuals), and in some cases made single or multi-year forecasts of revenues and earnings, (Gluck, 1980) but they did not develop formal strategic planning functions, systems, processes, tools, and methodologies, and did not systematically analyze the external environment, and assess internal competencies to formulate strategies prior to the 1960s. By the mid-1960s, however, strategic planning had become a business phenomenon (Stanford Research Institute, 1963) with Alfred Chandler providing the classic definition: "Strategy can be defined as the determination of the basic long-term goals and objectives of an enterprise, and the adoption of courses of action and the allocation of resources necessary for carrying out these goals" (1962, p.13).

\section{The Managerial School of Strategy}

Practicing executives such as Alfred Sloan at General Motors had demonstrated the need for strategic planning in the 1920s (Sloan, 1963). But, the formal study of the management functions underlying both leadership and strategy begins in earnest with Chester Barnard's The Functions of the Executive (1938), which identifies the key functions that place an organization's leadership at the center of strategic decision making. Peter Drucker, who claims to have written the first book on strategy in 1964 (Kiechel, 2010) also emphasized leadership's role in strategy, identifying three critical functions for leaders that remain the core of strategic planning today: formulate the strategy, implement the strategy, and monitor results and make course corrections (1973).

Igor Ansoff (1965), considered the father of planning (Mintzberg, 1994), kept management at the center of strategic decision making. Strategy might be affected, influenced, and in some cases constrained by external conditions, but in the end, it is the product of management decision making. Ansoff also provided a conceptual and methodological framework for formulating strategy, and expanded a number of concepts still central to strategic planning, including analyzing the external environment and assessing internal capabilities (essentially SWOT, Strengths, Weaknesses, Opportunities and Threats analysis), corporate competencies, and competitive advantage.

For Kenneth Andrews (1971), strategy provided the framework for the business policy capstone course taught at the Harvard Business School. The capstone course was based on case studies 
emphasizing the unique characteristics of each business and company (Kiechel, 2010). Strategic planning provided the unifying concept that integrated the critical managerial functions identified by Barnard, Drucker, Ansoff and others.

Andrews explicitly recognized the leader's role in both formulating and implementing strategy, and the skills needed to accomplish each (1971). Formulating strategy requires analytical and conceptual skills, implementing strategy requires administrative and interpersonal skills, and both require judgment because of the uncertainty inherent in strategic decision making. He expanded the core concept behind all strategic planning models - SWOT analysis- originally developed by Albert Humphrey at SRI in the 1960s (Humphrey, 2005). External opportunities and threats determined what the organization might do; internal strengths and weaknesses what the organization could do. As conceived by Andrews, SWOT analysis also included an important ethical dimension that extends the leader's role in strategic planning to her concept of the corporation's responsibilities to society, what they should do, and an important role for the personal values of the leaders in formulating strategy, what they want to do:

So far we have described the intellectual processes of ascertaining what a company might do in terms of environmental opportunity, of deciding what it can do in terms of ability and power, and bringing these two considerations together in optimal equilibrium. The determination of strategy also requires consideration of what alternatives are preferred by the chief executive and perhaps by his or her immediate associates as well, quite apart from economic considerations. Personal values, aspirations, and ideals do, and in our judgment quite properly should, influence the final choice of purposes. Thus what the executives of a company want to do must be brought into the strategic decision (1980, pp. 25-26).

Finally, Andrews observed that in addition to formulating and implementing strategy, leaders can have important indirect impacts on strategy through their personal leadership behavior:

.... executives do not affect their organizations only through their strategic choices. They also have impact through their influence over others, who in turn put forth effort and make choices affecting the organization's performance. Thus it is important that our conception of executive activity....extends beyond the realm of 'Strategic Choice,' to include 'executive behaviors'....the daily actions of executives, particularly in how they interact with others, can have a major effect on organizational functioning and performance (Finkelstein et al., 2009, p.72).

The leader for Andrews is thus both the chief architect and chief implementer of strategy. He is also the heart of the organization: "Though the spotlight of fashion today falls upon the business application of advanced research in the social science and in mathematical decision making, we can borrow from Emerson and say that a corporation is essentially the lengthened shadow of a man" (1971, p. 238).

\section{The Structural School of Strategy and the Great Divergence}

The practice of business strategy became dominated by strategic planning consultants in the mid1960s, who, unlike Barnard, Mintzberg, Drucker, Ansoff, and Andrews, greatly discounted if not totally dismissed the role of leadership in formulating and implementing strategy. The Boston 
Consulting Group (BCG), established by Bruce Henderson in 1963, became the leading proponent of the structural school of strategy (Kiechel, 2010) that cast aside leadership in favor of objective analyses of industry structure that would identify the optimal strategy dictated by external market conditions. The consultants developed a number of planning tools, concepts and techniques (e.g., the experience curve, growth-share matrices, forces of competition, value chains, and portfolio analysis) that firms eagerly applied to formulate strategies for their organizations based on the structure of the industry in which they competed. Henderson maintained that "....good strategy must be based primarily on logic, not....on experience derived from intuition" (1984, p.10). Implementation was ignored, or assumed to require no more than standard operating management.

The experience curve BCG developed launched the structural school of strategic planning and proved to be the single most important strategic planning concept ever developed (Kiechel, 2010). The experience curve purported to show that the unit cost of a product declines as experience in making it increases - a learning by doing phenomenon (Kiechel, 2010). Despite its significant shortcomings, (e.g., modifications to the product or new technologies could render past experience irrelevant) it became wildly popular across corporate America as the basis for formulating strategy.

BCG developed another wildly successful strategic planning tool in the late 1960s derived from the experience curve - the growth-share matrix. The growth-share matrix became the most popular planning tool over the next ten years with $45 \%$ of Fortune 500 and 36\% of Fortune 1,000 firms using some form of the matrix (Kiechel, 2010).

The growth-share matrix plotted market growth on the vertical axis, and market share on the horizontal axis. The rate of market growth indicated the company's sources of and needs for cash - businesses in slow growing markets generated the cash needed by businesses competing in rapidly growing markets. Market share (relative to the next largest competitor) determined competitive position - higher share meant higher production that translated into lower cost via the experience curve.

A company's businesses (strategic business units) were placed in one of the four quadrants in the matrix: star (low cost position in high growth market), cash cow (low cost position in low growth market), dog (high cost position in low growth market), or question mark (high cost position in high growth market) with clear strategic implications for each business and for overall corporate strategy. The excess cash from cows is used to fund the growth of star businesses. Investments had to be made in question marks to turn them into future stars, or the question marks had to be harvested. Dogs had to be divested. Jack Welch's business strategy at General Electric focused on growth and requiring all business units to be number one or two in their markets and was a hugely successful application of the growth-share matrix (Kiechel, 2010).

McKinsey entered the lucrative mainstream of strategic consulting with the introduction of the McKinsey-GE 9-cell matrix that it developed with General Electric in 1971 (Hax and Majluf, 1984). General Electric was the leading practitioner of strategic business planning under the leadership of Chief Executive Officers Reginald Jones, and later, Jack Welch. Rather than base its strategies on the two factors in the BCG growth-share matrix, GE worked with McKinsey to develop the 9-cell matrix that assessed numerous variables affecting industry attractiveness and competitive position in addition to the rate of market growth and relative market share. 
The 9-cell matrix was more detailed, complex, qualitative, and subjective than the BCG growthshare matrix, but had similar implications for strategy based on the structure of the industry, and the competitive position of the company in the industry. Industry attractiveness was determined by assessing a number of important characteristics of the industry (e.g., number/size of competitors, entry conditions) in addition to market growth; competitiveness was assessed by evaluating a number of relevant company factors (e.g., brand image, labor costs) in addition to relative market share.

Michael Porter (1980) has arguably exerted more influence over strategic planning than any other student of strategy over the past fifty years. Perhaps his most important contribution to planning was adapting the economists' structure-conduct-performance model (SCP) developed by Edward Mason (1949) and Joe Bain (1956) to assist economic policy making to the challenges facing strategic planners. He bridged the gap between economics and business by turning industrial organization on its head (Kiechel, 2010). Where economists were interested in the implications of industry structure for public policy, and in minimizing excess profits, Porter was interested in the implications of industry structure for business strategy, and for maximizing profits.

The SCP model posits that the structure of the industry determines how vigorously firms compete (conduct) in, for example, setting prices, with more vigorous competition leading to lower profits (performance). The five forces of competition in the Porter model (1980), threat of new entrants, the bargaining power of buyers and suppliers, substitute products, and competition among existing rivals, mirror industry structure in the SCP model. Competition is vigorous, and the prospects for superior profits poor in industries where the five forces are strong. Such industries are best avoided. Strategies for more attractive industries are dictated by the five forces: take preemptive actions to discourage new firms from entering the industry, reduce reliance on strong buyers and suppliers, and differentiate products to diminish threats from substitute products.

The most biting criticism leveled against Porter and the structuralist model was simply: "Where are the people in a Michael Porter strategy?" (Kiechel, 2010, p. 7). Porter and the structuralists did not, perhaps, dismiss the role of leadership in strategy to the extent economists did in the SCP model where homo economicus was limited to equating costs and revenues at the margin, but management's role was limited to the "standard good operating management" Henderson assumed every company had (Kiechel, 2010, p. 140). In stark contrast, Andrews concluded that "One of the principal impediments to effective implementation of plans is a shortage of management manpower...." (1971, p. 220).

While the structuralists can be criticized for minimizing the role of leadership in strategy, the influence of the external environment cannot be ignored. Even Montgomery cautions: "Don't be trapped by the myth that your superior management skills will carry you to success.... whatever you do, don't underestimate the power of these forces [Michael Porter's five forces of competition]. Their impact on the destiny of your business may well be as great as your own...." (2012, p. 37). Or as put more starkly by Dick Foster of McKinsey: "In the long run, markets always win" (Foster as cited in Kiechel, 2010, p. 167).

New Roles for Leadership in Strategy 
Studies showing that only $10 \%$ of firms were able to implement strategy effectively, more than any other single factor, rekindled interest in the role of leadership in strategy (Kiechel, 2010). Unlike the strategy consultants, Drucker (1973), Pascale and Athos (1981), Peters and Waterman (1982), Mintzberg (1973), Collins (2001), Kotter (1982), and Kanter (1983), among numerous others, discovered new strategic roles for leadership in the dynamics of adaptation, change management, organizational learning, and other dimensions of strategy that challenged the structural school's assumption that "standard good operating management" was all that was required.

Pascale's study (1984) of Honda's successful entry into the U.S. motorcycle market in 1959 presented a direct challenge to the structuralist school. Pascale discovered that the Japanese executives who led this effort had no strategy: "In truth, we had no strategy other than the idea of seeing if we could sell something in the United States" (1984, p. 54). Honda succeeded through experimentation, adaptation, learning, and serendipity. Pascale concluded from this that rather than simply choosing the optimal strategy dictated by the structure of the industry, the task of leadership is to continuously develop and enhance competitive strategies through adaptation and learning.

Tom Peters and Robert Waterman's In Search of Excellence (1982) raised another serious challenge to the structural school. They describe excellent companies as those that implement strategy by effectively aligning the factors in the 7-S model (the company's strategy must be aligned with its structure, systems, staff, style, skills, and superordinate goals) introduced by Pascale and Athos (1981). They maintain that the crucial problems in strategy are execution and continuous adaptation. Managerial excellence and people, not industry structure, are what matter for Peters and Waterman (1982).

Perhaps the most caustic criticisms of the structural school and of strategic planning come from Mintzberg who maintains that strategies 'emerge' from managerial intuition, synthesis, past behaviors, adaptations, and learning rather than from formal planning (1994). Leadership plays a key role in strategy formulation and implementation, but not through a formal planning process. He explains that strategies grow “.... like weeds in a garden, they are not cultivated like tomatoes in a hothouse" (Mintzberg, 1989, p. 214). He elaborates: "Organizations engage in formal planning, not to create strategies but to program the strategies they already have, that is, to elaborate and operationalize their consequences formally" (Mintzberg, 1994, p. 333).

These and other studies rekindled interest in the role of leadership in strategy, but leadership made only limited inroads into strategic planning, primarily in implementing strategy, despite biting criticisms of its absence in the structural model. One reason for these limited inroads is the lack of a comprehensive theory of leadership that encompasses strategy formulation and implementation.

\section{Leadership}

The study of leadership has its roots in Egyptian rulers (Ptah-Hotep, 2880 BCE), Greek heroes (Homer, 800 BCE), Chinese Generals, (Sun Tzu, 500 BCE), Persian Kings (Xenophon, 375 BCE), and Italian princes, (Machiavelli, 1513) but it has been the subject of intense academic study only the past sixty years, and most particularly the past twenty. 
Denied any substantive role in the formulation and implementation of strategy by the consultants, leadership proceeded down new paths, carving out what would become its exclusive domains as illustrated by one typical textbook definition of leadership as ".... the process of influencing an organized group toward accomplishing its goals" (Hughes et al. 2009, p. 24). The emphases on process and influence capture much that is essential to leadership, but this definition, like most others, reflects the clear separation of leadership from strategy with its failure to acknowledge either formulating or implementing strategy -- the core responsibilities of leadership.

\section{Trait Theories (1930s)}

Investigations of personality traits were one of the earliest approaches to the study of leadership. These studies were based on the premise that leaders are born (traits are inherited) and not made. The physical (height), mental (intelligence), and social (personality) traits of noted leaders are observed, but the atheoretical observations provide no explanation of how these traits affect leadership. At its worst, the trait approach is little more than hero worship, exulting the accomplishments and characteristics of the world's most successful leaders.

Indeed, early trait theories of leadership were known as Great Man theories (Hughes et al., 2009; Stogdil, 1974). Thomas Carlyle wrote that "The history of the world is but the biography of great men" $(1888$, p. 2). Napoleon elaborated: "Men are nothing; it is the man who is everything.... It was not the Roman army that conquered Gaul, but Caesar; it was not the Carthaginian army that made Rome tremble in her gates, but Hannibal, it was not the Macedonian army that reached the Indus, but Alexander" (Hughes et al., 2009, p. 132).

Research based on leadership traits was largely abandoned in the 1950s because it failed to identify any universal traits that distinguished effective leaders from others (Stogdill, 1948).

\section{Behavioral Theories (1940s and 1950s)}

Unable to find universal traits that distinguish great leaders from others, researchers largely abandoned the trait approach for studies of behaviors that were considered more important to effective leadership than the leader's physical, mental or emotional traits. Two studies initiated at Ohio State University (Hemphill and Coons, 1957) and the University of Michigan (Bowers and Seashore, 1966) provided the foundation for numerous behavioral studies of leadership.

The Ohio State study found two basic behaviors important to effective leadership -consideration and initiating structure. Consideration (employee oriented behavior) emphasizes support for and recognition of subordinates. Initiating structure (task-oriented behavior) focuses on planning and coordinating work. The University of Michigan study drew a similar dichotomy between employee (interpersonal relations) and production (task) orientated behaviors.

However, like the earlier trait studies, these and other behavioral studies failed to find consistent relationships between behavior and leadership effectiveness.

\section{Contingency Theories (1960s and 1970s)}

Contingency theories that explore the impact of the situation on leadership were developed in the 1960s and 1970s in part to explain the lack of empirical relationships among leadership traits, behaviors, and effectiveness. The impacts of leadership traits and behaviors on performance 
could be influenced (moderated) by the situation. The abilities, skills, goals, aspirations and behaviors of followers, and the characteristics of the environment were all studied in contingency models.

Fred Fiedler (1967) was among the first to research how the situation interacts with leadership traits and behaviors to influence leadership effectiveness. House's path-goal theory (1971) argued that employee characteristics (experience and ability) and the nature of the task both determined which leadership behaviors were most effective. While contingency theories of leadership recognize the impacts of numerous dimensions of the situation on leadership, market growth, industry structure, competitive position, core competencies, and other factors critical to leadership's roles in formulating and implementing strategy are ignored.

\section{Substitutes-for-Leadership Theories (1970s)}

Substitutes-for-leadership theories, like other contingency theories, also developed in the late 1970s to help explain the lack of empirical evidence demonstrating the impacts of leadership traits and behaviors on effectiveness. These theories postulate that certain characteristics of the organization (e.g., group cohesiveness and norms), the task (e.g., highly structured, routine, intrinsically satisfying), and the followers (e.g., professionalism, training, experience) may lessen, substitute for, or negate the effects of leadership on performance (Daft, 2011; DuBrin, 2013; Hughes et al., 2009; Kerr and Jermier, 1978). Substitutes-for-leadership theories, with organizational characteristics substituting for formal leadership, bear a kinship to Mintzberg's (1994) theory of strategy in which the strategy emerges from organizational processes and actions outside the formal strategic planning process.

\section{Transformational Leadership (1970s and 1980s)}

Transformational leadership is distinguished by extraordinary relationships between a (charismatic) leader and followers that lead to superior performance e.g., turning around a failing company. Charisma is not a personality trait per se, but a relationship between leaders and followers attributable in large measure to the leader's personality. In contrast to transactional leadership that relies on tasks, rewards, and punishments to motivate followers (e.g., exchange and path-goal theories), transformational leadership is built on mutual trust, devotion, reverence, and loyalty-- goals that supersede self-interest, a compelling vision typically with high moral content, and exemplary personal behavior (sacrifice) by the leader that inspires subordinates (Bass, 1985; Hughes et al., 2009).

Transformational leadership, like personal leadership behavior in the Andrews model (1971), can have (powerful) indirect impacts on formulating and implementing strategy:

.... this study, as well as other research on charisma (and 'transformational leadership') highlights that executives do not affect their organizations only through their strategic choices. They also have impact through their influence over others, who in turn put forth effort and make choices affecting the organization's performance. Thus it is important that our conception of executive activity....extends beyond the realm of 'Strategic Choice,' to include 'executive behaviors'....the daily actions of executives, particularly in how they interact with others, can have a major effect on organizational functioning and performance (Finkelstein et al., 2009, p.72). 


\section{Strategic Leadership}

Strategic leadership focuses on strategic decision making by giving the organization's top executives (Boards of Directors, Chief Executive Officers, Executive Committees, and Divisional Heads) ultimate responsibilities for formulating and implementing strategy (Finkelstein et al., 2009). The strategic leadership literature, like Andrews, recognizes the critical roles (top level) leaders play as both formulators and implementers of strategy, and that the decisions and actions of the leaders reflect their idiosyncratic experiences, motives, dispositions, tolerances for risks, and basic values:

....the mainstay constructs of strategic management researchers - factors such as the environment, competitors, allies and the company's resources - will provide us woefully incomplete explanations of company behaviors. Instead, we need to also consider, in an integral way, the biases and dispositions of the people at the top of the firm. In doing so, we will find that human factors - deriving from personality, experience, values, social connections, fatigue, envy, and so on - play a substantial role in affecting organizational outcomes (Finkelstein et al., 2009, p.4).

Strategic leadership recognizes the constraints imposed on strategy choice by the external environment, but does not give the structuralists a blank check. There is a substantial role for leadership in strategy, especially in 'weak' situations where external circumstances do not dictate a clear course of action because of uncertainty, ambiguity, or information overload: “....bounded rationality, multiple and sometimes incompatible goals, myriad options, and varying aspirational levels all serve to limit the extent to which complex decisions can be made on a techno-economic basis" (Finkelstein et al., 2009, p.44). Finkelstein, Hambrick and Cannella conclude that "Depending on how much discretion exists, an organization's form and fate may lie totally outside the control of its top managers, completely within their control, or more typically, somewhere in between" (Finkelstein et al., p. 26).

\section{Globalization}

Globalization has added new dimensions to strategy and leadership and made both more complex, raising new challenges to both the structural and managerial schools and widening the gap between leadership and strategy. Importantly, globalization creates the classic 'weak' situation where the quantity, variability, uncertainty, and ambiguity of information test the limits of both the structural and managerial approaches to strategy. Structuralists search for more sophisticated planning tools that can cope with the heightened variability in the global, external environment. The managerial school emphasizes the leadership traits, behaviors, competencies, skills and 'global mindsets' needed to cope with the greater complexity, ambiguity and uncertainty globalization creates (Mendenhall, 2013). Both responses enhance the abilities of organizations to meet the challenges of globalization, but the strategic decision-making skills of leaders may be the critical competency that differentiates successful from unsuccessful companies in these 'weak' situations.

\section{An Integrated Approach to Teaching Leadership and Strategy}

Leadership and strategy were fully integrated in practice and in the classroom in the mid-1960s. Students mastered the analytical and interpersonal skills leaders need to formulate and 
implement strategy. However, the gulf between leadership and strategy that opened up in the mid-1960s has steadily widened as the two disciplines have proceeded down divergent paths, focused on their expanding, exclusive domains, and responded to the challenges of globalization.

The separation of leadership and strategy manifests itself in the classroom where each concentrates on its exclusive domain - there is no or minimal discussion of strategy in the leadership class, and no or minimal discussion of leadership in the strategy class. Critical functions, interactions, the contexts for decision making and purposeful behavior, and much that is essential to both effective leadership and strategy are concealed in the black boxes substituting for strategy and leadership in Figures 1and 2.

Figure 1: The Impacts of the Situation/Followers on Leadership and Performance

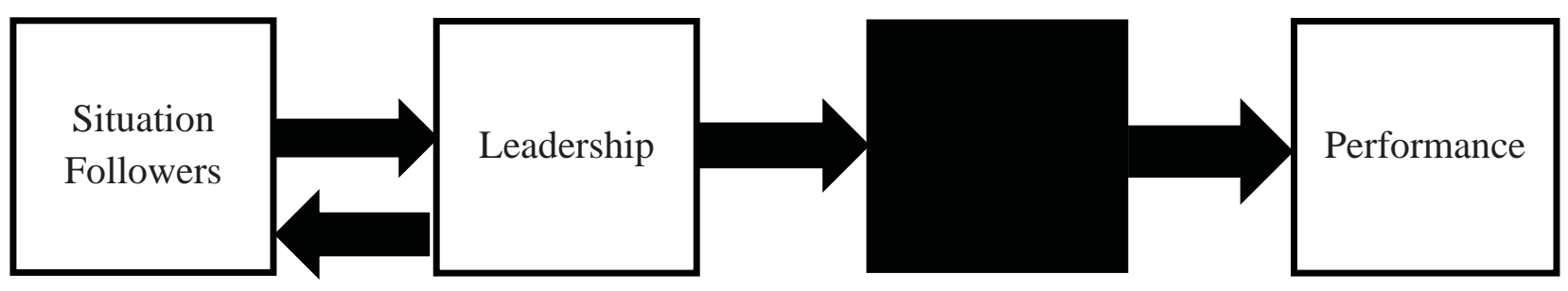

Figure 2: The Impacts of the Situation/Followers on Strategy and Performance

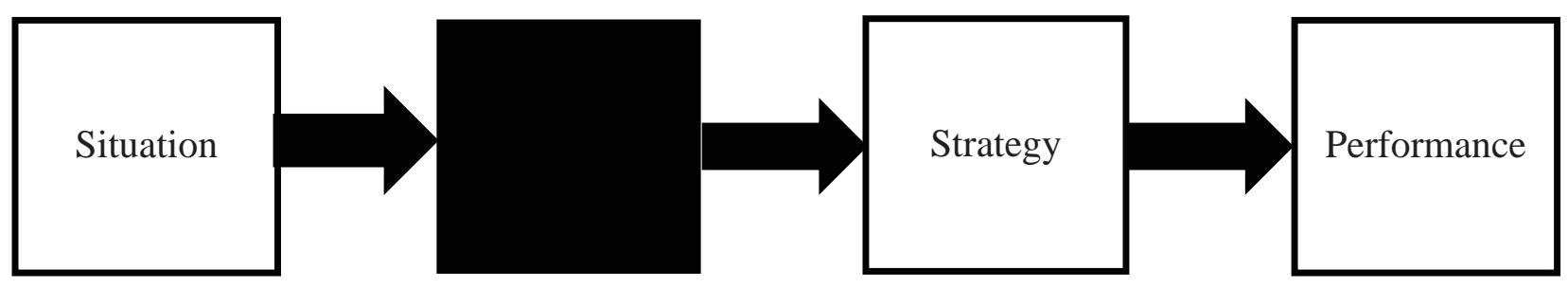

Students in the leadership class are taught that the situation/followers affect leadership, how to adapt their behavior to the demands of the situation, and how to motivate their followers. However, as shown in Figure 1, the formulation and implementation of strategy for which they are responsible is replaced with a black box. Without strategy, the study of leadership is vacuous. Absent strategy, the leader has no basis for determining how to respond to the situation, how to adapt her behavior to the needs of her followers, or how or for what purposes to motivate followers. Strategy provides the needed polestar for determining appropriate leadership responses to the situation/followers. 
The lack of empirical evidence supporting the effects of leadership on organizational performance is also largely the consequence of substituting a black box for strategy in Figure 1. Without strategy, the leader cannot know if her leadership has positive, neutral, or negative effects on organizational performance. The effects of leadership on performance are limited to its indirect effects on followers that, like personal leadership behavior in the Andrews (1971) model, are simply assumed to have generally positive effects on performance; the critical direct impacts of leadership on performance through formulating and implementing strategy are ignored.

Students in the strategy class are taught that the situation (e.g., industry structure) dictates the strategy. The leadership that formulates and implements that strategy is absent in Figure 2. With leadership absent, however, there is no mechanism for formulating a strategic response to the situation that encompasses corporate vision, objectives, values, skills, core competencies, or leadership experience, insight, intuition, judgment, values, and preferences. These and other factors that affect strategy, and the impacts of uncertainty, ambiguity, risks, and conflict on strategic decision making are concealed in the black box substituting for leadership in Figure 2. The strategy simply appears deus ex machina.

The integrated approach to teaching leadership and strategy requires the leadership class to explicitly examine the leader's responsibilities for formulating and implementing strategy, and develop the analytical, interpersonal, and decision-making skills leaders need to perform these core functions. It must replace the black box separating leadership and organizational performance with the strategy the leadership develops to achieve the organization's goals. The strategy class needs to explicitly examine how leadership affects the development, choice, and implementation of strategy, replacing the black box separating the situation and strategy with the leadership responsible for formulating and implementing that strategy.

Figure 3 illustrates the integrated approach to teaching leadership and strategy that is necessary to prepare today's students for the leadership challenges they will face in the $21^{\text {st }}$ Century global economy. The comprehensive integrated model for teaching leadership and strategy encompasses the direct, indirect, and mediating interactions among the situation/followers, leadership, strategy, and performance. Students need to grasp the full scope of these numerous, complex interactions to understand their roles, functions and responsibilities as future leaders, and the full consequences of their actions. They need to understand the whole beast before tugging on its tail or pulling on its tusks. 
Figure 3: An Integrated Approach to Teaching Leadership and Strategy

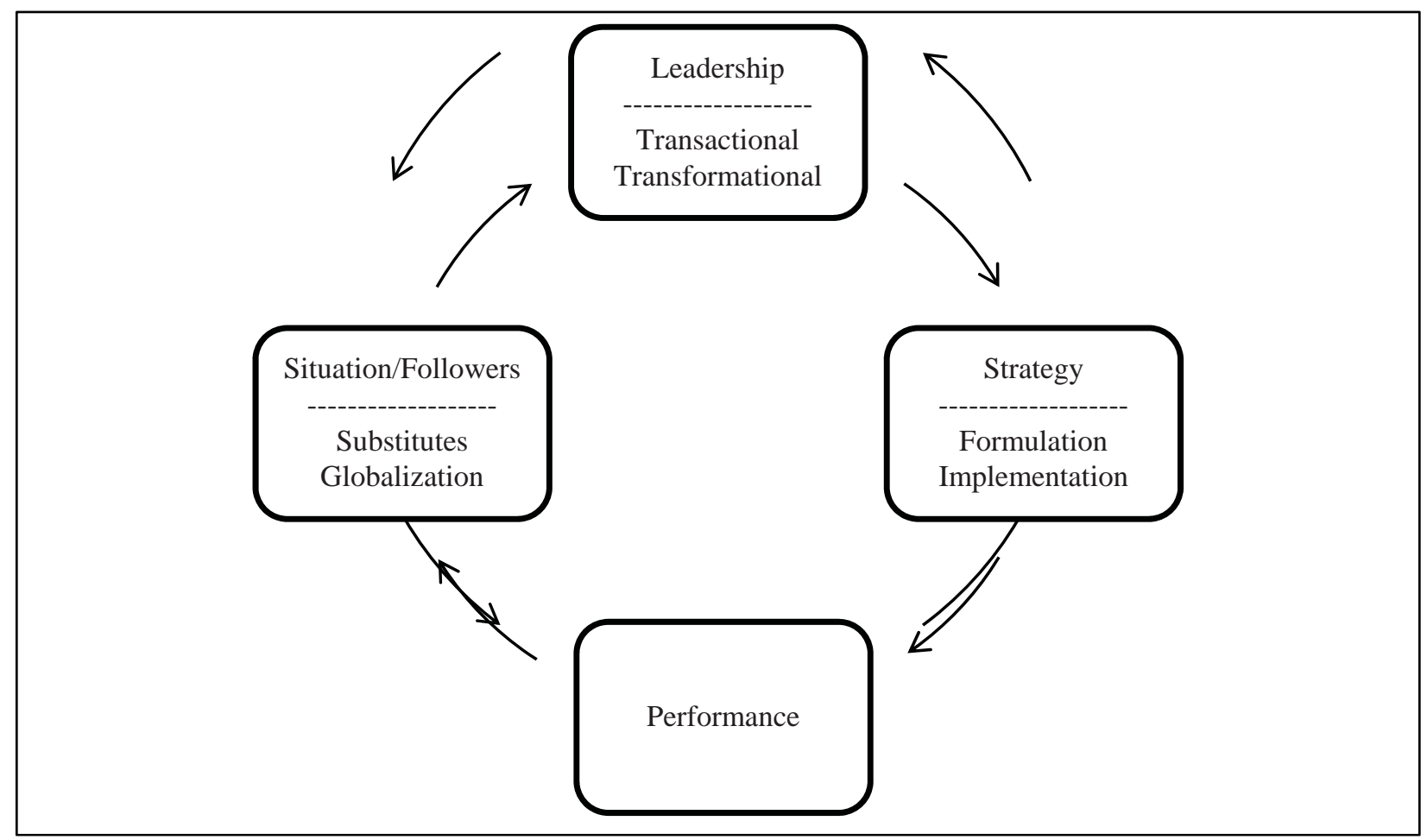

Figure 3 illuminates the direct effects (clockwise) of the situation (external environment) and followers (core competencies) on leadership. It shows how leadership mediates the effects of the situation/followers on strategy formulation and implementation, the direct effects of strategy on organizational performance, and, finally, the impacts of performance on the initial situation and followers. Figure 3 also shows the indirect effects (counter clockwise) of leadership on followers and how these effects on followers mediate leadership's indirect impacts on performance as emphasized by Andrews (1971), and the indirect effects of performance on strategy, essentially by changing the initial situation. Finally, the loop is closed in Figure 3 with the indirect effects of strategy on leadership. One can argue that leadership affects strategy or not, but strategy does affect leadership through its effects on the selection of leaders whose experience, traits, and skills are compatible with the organization's strategy: "Over time, a reinforcing spiral probably occurs: managers select strategies that mirror their beliefs and preferences; successors are selected according to how much their qualities fit the strategy, and so on" (Finkelstein, et al., 2009, p. 115). Strategy also indirectly affects leadership through its impacts on performance and the situation. Closing the loop in Figure 3 thus yields valuable insights into how leadership and strategy evolve over time, and coalesce within an organization.

\section{Alternative Leadership Theories}

The integrated approach to teaching leadership and strategy enables the student to grasp the fundamental responsibilities of leadership for formulating and implementing strategy, and manage the multiple interactions among the situation, leadership, strategy, and performance. It also enables alternative theories of leadership and strategy to be treated as core concepts instead 
of tangential factors of little value to future leaders. Within the integrated approach, alternative theories such as substitutes for leadership and planning, transformational leadership, and globalization can readily be treated as integral components of leadership and strategy that hold valuable lessons for future leaders.

\section{Substitutes for Leadership and Planning}

Leadership is not always essential. Rules, routines, employee experience and skills, and organizational culture can sometimes substitute for leadership (Kerr and Jermier, 1978). Similarly, formal planning is not always necessary. Mintzberg maintains that strategy can 'emerge' from past actions, learning, and intuition outside the formal planning process (Mintzberg, 1994), and that strategies grow “.... like weeds in a garden, they are not cultivated like tomatoes in a hothouse" (Mintzberg, 1989, p. 214). He explains: "Organizations engage in formal planning, not to create strategies but to program the strategies they already have, that is, to elaborate and operationalize their consequences formally" (Mintzberg, 1994, p. 333).

These substitutes for leadership and planning are readily captured in the integrated approach to leadership and strategy in Figure 3 as components of the situation/followers that directly affect the roles, functions, tasks, and responsibilities of leaders. The integrated approach shows how leaders interact with these informal processes to mediate their impacts on the formulation and implementation of strategy. It also shows the indirect effects of leadership on these informal processes as leaders adapt to the impacts of these substitutes on their roles and responsibilities.

\section{Transformational Leadership}

Transformational leadership can have powerful impacts on organizational performance (Finkelstein et al., 2009). But, without an integrated approach to leadership and strategy, the tangential effects of transformational leadership on performance are, like Andrews' personal leadership behavior (1971), limited to general indirect effects via inspired followers. However, transformational leaders, no less than transactional leaders, are responsible for formulating and implementing strategy. In the integrated approach in Figure 3, transformational leadership affects performance through its direct effects on strategy as well as through its indirect effects on followers. Leaders purposely utilize their extraordinary influence over followers to more effectively create and implement strategy.

\section{Globalization}

Globalization has dramatic effects on the situation (e.g., industry structure) and followers (e.g., multi-cultural work forces) that impact the leadership that mediates the effects of the (global) situation on (global) strategy. It is thus essential to capture the direct impacts of globalization on leadership and ultimately strategy as shown in Figure 3. The daunting challenges of adapting leadership style and behavior to the global situation, and to the needs of global followers are also captured in the indirect effects of leadership on the situation/followers in Figure 3.

As noted, globalization creates the classic 'weak' situation where increased uncertainty tests the limits of both the structural and managerial approaches to strategy. Structuralists respond with more sophisticated planning tools and global models; the managerial school with new leadership competencies, skills, and 'mindsets' (Mendenhall, 2013). The integrated approach to teaching leadership and strategy readily accommodates the responses of both schools to the challenges of 
globalization with (global) leadership mediating the impacts of the (global) situation on the (global) strategy.

The structural school cannot develop new global strategies in response to globalization absent the strategic decision-making skills and 'global mindsets' that, more than any other factor, distinguish successful from unsuccessful companies in these 'weak' situations. The managerial school cannot respond to the challenges of globalization or develop the needed mindsets without the context provided by global strategy.

\section{Recommendations and Implications}

This paper has a number of implications for future research, and for the practice and teaching of leadership and strategy.

\section{Research}

Focused on more effectively integrating the practice and teaching of leadership and strategy, the paper suggests several productive avenues for future leadership research. New insights into leadership could be generated by employing more comprehensive research models that capture the direct, indirect, and feedback interactions among the situation/followers, leadership, strategy, and organizational performance. New insights could come from replacing linear regression, analysis of variance, and correlation models that isolate a single feature of leadership, and that are ambiguous about causation with more sophisticated mediation and moderation models that would, for example, show how the effects of leadership on performance are operationalized (mediated) through strategy. These more advanced research models would essentially unlock the black boxes in Figure 3 that conceal much that is relevant to understanding leadership and its impacts on organizational performance.

Studies of the effectiveness of leadership traits, behaviors, styles, and types (e.g., servant, empathic, authentic, entrepreneurial, and transformational) could generate new insights from being undertaken in the context of the organization's external competitive environment (e.g., Michael Porter's five forces of competition), competitive position (e.g., position on BCG's growth-share matrix as a star, cash cow, question mark, or dog), and competitive strategy (low cost, differentiation, niche, blue ocean, or global). Such studies would link leadership effectiveness directly to its primary responsibilities for formulating and implementing strategy. For example, studies could show transformational leadership's powerful impacts on performance through its effects on the formulation and implementation of organizational strategy in addition to its general positive effects on morale and motivation.

Research exploring the impacts of globalization on leadership could help prepare students better for the challenges they will face as future leaders in global organizations. This paper suggests that such studies would be most productive if undertaken in the context of the organization's global business environment and strategy. They could also produce important new insights by exploring the leadership implications of the 'weak' situations (heightened information variability, uncertainty, ambiguity, and accelerated pace of change) that confront global leaders.

Studies of leadership that explore how planning systems (e.g., formal vs. 'emergent') affect leadership roles and responsibilities, how the leader's personal values, goals, and aspirations 
affect the choice of strategy, and how leadership recruitment, development, succession planning, and turnover relate to the organization's strategy, and the feedback effects of strategy on leadership, could all lead to new insights into effective leadership.

\section{Practice}

The most important implication of this paper for practitioners is that leaders must balance external environmental and human factors in fulfilling their responsibilities. Effective leaders are both left and right brain thinkers. They objectively analyze, interpret, and assess the external environment, and identify the opportunities it presents as well as the constraints it imposes on them as leaders. They understand that the external environment influences their actions, decisions, and behavior, but does not dictate them. They know how to combine experience, intuition, and judgment with objective analyses to lead effectively.

\section{Teaching}

Leadership is not a course in strategy. However, this paper suggests that leadership classes would be of greater practical value to future leaders if they explicitly recognized and explored the leader's roles in formulating and implementing organizational strategy. This could largely be accomplished by including discussions of the common origins of leadership and strategy, their evolution, the leader's operative role in strategy, the divergence of leadership and strategy in the 1960s, and the need for re-convergence in the introduction to the leadership class.

Expanding classroom discussions of leadership traits, behaviors, styles, skills, types, and effectiveness to include the interactions among the situation/followers, leadership, strategy and organizational performance shown in Figure 3would add new dimensions, specificity, and practical value to the study of leadership. Importantly, it would help students better understand how, when, and where in their organizations to apply the leadership tools, techniques, and principles learned in the classroom.

These discussions could be effectively supplemented with a number of typical leadership classrooms activities:

- Case Studies: Assign cases that provide background information on the company's competitive environment, position, and strategy against which the effectiveness of leadership behavior, style, skills, and actions can be assessed.

- Great Leaders: Assess the effectiveness of outstanding past leaders in terms of their ability to successfully formulate and implement innovative strategies.

- Observational Exercises: Observe, interview, or survey current leaders to determine if their leadership behavior and style are consistent with the organization's goals and strategy.

- Written Reports: Compare and contrast the leadership behaviors, styles, and skills of leaders from organizations pursuing different strategies.

- Role Playing: Assign students to play the roles of leaders facing critical decisions in organizations with different business strategies (low-cost, differentiation, niche, blue ocean, global). 
- Group Activities: Assign groups the tasks of selecting new leaders for business units in the organization that are in different competitive positions (e.g., stars, cash cows, question marks, or dogs).

- Reflection Papers: Include student reflections on personal experiences with formulating and implementing strategy.

\section{Summary and Conclusions}

Leadership and strategy developed together thousands of years ago to meet basic human needs. Early academic studies preserved this natural alliance. The estrangement began in the mid-1960s with the appearance of the strategy consultants who minimized, if not eliminated, the role of leadership in formulating and implementing strategy in favor of mechanically identifying optimal strategies based on objective analyses of the external environment.

Failures in implementing strategy in the 1980s led to new roles for executives as leaders, but not as strategists. As leaders, they assumed limited responsibilities for implementing strategies they had no role in formulating.

The resulting separation of leadership and strategy in the classroom conceals critical interactions among leadership and strategy in black boxes that are of no instructional value. These black boxes are pried open in the integrated model of leadership and strategy in Figure 3 to reveal the continuous interplay of direct, indirect, and mediating effects among the situation, leadership, strategy, and organizational performance.

The ultimate consequence of the separation of leadership and strategy in the classroom is that students are not adequately prepared to be effective leaders. They do not understand their primary leadership responsibilities for strategy development and implementation, how to determine appropriate leadership responses to different situations/followers, when or how to apply the leadership concepts, principles, and skills they have learned, or even how to assess the effectiveness of their leadership on organizational performance. It is thus essential to integrate the teaching of leadership and strategy to more effectively prepare students for the responsibilities they will assume as future leaders by clarifying their core leadership functions and responsibilities, arming them with the analytical and interpersonal skills needed to meet these responsibilities, and providing the strategic context for effectively applying these skills to achieve organizational goals. 


\section{References}

Andrews, K.R. (1971). The concept of corporate strategy. Homewood, IL: Dow Jones-Irwin.

Andrews, K.R. (1980). The concept of corporate strategy (Rev. ed.) Homewood, IL: Richard D. Irwin.

Ansoff, H.I. (1965). Corporate strategy. New York, NY: McGraw Hill.

Bain, J.S. (1956). Barriers to new competition. Cambridge, MA: Harvard University Press.

Bass, B.M. (1985) Leadership and performance beyond expectations. New York, NY: The Free Press.

Barnard, C.I. (1938). Functions of the executive. Cambridge, MA: Harvard University Press.

Bowers, D.G., \& Seashore, S.E. (1966). Predicting organizational effectiveness with a four factor theory of leadership. Administrative Science Quarterly, 11, 238-63.

Carlyle, T. (1888). On heroes, hero-worship and the heroic in history. New York, NY: Fredrick A. Stokes and Brother.

Chandler, A.D. (1962). Strategy and structure: Chapters in the history of the American industrial enterprise. Cambridge, MA: MIT Press.

Collins, J. (2001). Good to great. New York, NY: HarperCollins.

Daft, R.L. (2011). The leadership experience ( $5^{\text {th }}$ ed.). Mason, OH: South-Western.

Drucker, P.F. (1946). Concept of the corporation. New York, NY: John Day and Co.

Drucker, P.F. (1973). Management: Tasks, responsibilities, and practices. New York, NY: Harper \& Row.

DuBrin, A.J. (2013). Leadership (7 $7^{\text {th }}$ ed.). Mason, OH: South Western.

Fiedler, F.E. (1967). A theory of leadership effectiveness. New York, NY: McGraw-Hill.

Finkelstein, S., Hambrick D.C. \& Cannella, A.A. (2009). Strategic leadership: theory and research on executives, top management teams, and boards. New York, NY: Oxford University Press.

Gluck, F.W., Kaufman, S.P., \& Walleck, A.S. (1980). Strategic management for competitive advantage. Harvard Business Review 58(4), pp. 154-161.

Hart, B.H.L. (1967). Strategy. New York, NY: Frederick A. Praeger.

Hax, A.C. \& Majluf, N.S. (1984). Strategic management: An integrative perspective. Englewood Cliffs, NJ: Prentice Hall. 
Hemphill, J.K. \& Coons, A.E. (1957) Development of the leader behavior description questionnaire. In R. Stodgily \& A. Coons (Eds.), Leader behavior: Its description and measurement. Columbus, OH: Ohio State University, Bureau of Business Research.

Henderson, B.D. (1984). The logic of business strategy. Cambridge, MA: Boston Consulting Group.

Homer. (1990). Robert Flagles (Trans.). The Iliad. New York, NY: Penguin Group.

House, R.J. (1971). A path-goal theory of leader effectiveness. Administrative Science Quarterly 16.

Hughes, R.L., Ginnett, R.C., \& Curphy, G.J. (2009). Leadership: Enhancing the lessons of experience ( $6^{\text {th }}$ ed.). New York, NY: McGraw Hill- Irwin.

Humphrey, A.S. (2005). SWOT analysis for management consulting. SRI alumni Association Newsletter. December, pp. 7-8.

Kanter, R.M. (1983) The change masters. New York, NY: Simon and Schuster.

Kerr, S. \& Jermier, J.M. (1978). Substitutes for leadership: Their meaning and measurement. Organizational Behavior and Human Performance 22, 375-403.

Kiechel, W. (2010). The lords of strategy. Boston, MA: Harvard Business Press.

Kotter, J.P. (1982). The general managers. New York, NY: The Free Press.

Machiavelli, N. (1979). P. Bondanella \& M. Musa (Trans.). The prince. Oxford, Kingdom: Oxford University Press.

Mason, E. (1949). The current state of the monopoly problem in the U.S. Harvard Law Review, $62,1265-85$.

Mendenhall, M.E. (2013). Leadership and the birth of global leadership. In M. Mendenhall, J. Osland, A. Bird, G. Oddou, M. Maznevski, M. Stevens \& G. Stahl (Eds.) Global Leadership (2 ${ }^{\text {nd }}$ ed.). (pp.1-20). New York, NY: Routledge.

Mintzberg, H. (1973). The nature of managerial work. New York, NY: Harper \& Row.

Mintzberg, H. (1989). Mintzberg on management: Inside our strange world of organizations. New York, NY: The Free Press.

Mintzberg, H. (1994). Mintzberg, H. (1994). The rise and fall of strategic planning. New York, NY: The Free Press.

Montgomery, C.A. (2012). The strategist. New York, NY: HarperCollins.

Musashi, M. (1974). V. Harris (Trans.). A book of five rings. Woodstock, NY: The Overlook Press. 
Northouse, P.G. (2013). Leadership: theory and practice (6 ${ }^{\text {th }}$ ed.). Thousand Oaks, CA: Sage Publications.

Pascale, R.T. \& Athos, A.G. (1981). The art of Japanese management. New York, NY: Warner Books.

Pascale, R.T. (1984). Perspectives on strategy; The real story behind Honda's success. California Management Review, 26, 3,Spring, pp. 47-72.

Peters, T.H. \& Waterman, R.H. (1982). In search of excellence. New York, NY: Harper \& Row.

Porter, M.E. (1980). Competitive strategy: Techniques for analyzing industries and competitors. New York, NY: The Free Press.

Ptah-Hotep. (2880BCE). The maxims of Ptah-Hotep. Charles F. Horne (Ed.) The sacred books and early literature of the east (1917). Vol. II: Egypt, pp. 62-78. New York NY: Parke, Austin \& Lipscomb.

Stanford Research Institute (1963) Planning in business. Menlo Park: Stanford Research Institute.

Sloan, A.P. (1963) My years with General Motors. New York, NY: Doubleday \& Company.

Stogdill, R.M. (1948). Personal factors associated with leadership: A survey of the literature. Journal of Psychology 2.5.

Stogdill, R.M. (1974). Handbook of leadership. New York, NY: The Free Press.

Sun-Tzu. (1994). R. Sawyer (Trans.). The art of war. New York, NY: Barnes \& Noble.

Von Clausewitz, C. (1982). A. Rapoport (Ed.). On war. London, England: Penguin Books.

Xenophon (n.d.). H. Dakyns (Trans.). Cyropaedia: The education of Cyrus. U.S.A: Dodo Press.

\section{Author Biography}

Professor Marx holds a BS in Business Administration (Summa cum laude) from Ryder University, and Ph.D. in Economics from the Wharton School at the University of Pennsylvania. He worked for the Federal Trade Commission for 5 years following graduation, and then for General Motors Corporation for 28 years where he held a number of leadership and strategic business planning positions, including Director of Plans Consolidation for the Corporate Strategic Planning Staff. Dr. Marx joined the faculty at Lawrence Technological University in 2005. Dr. Marx teaches Global Leadership and Global Strategic Management in the MBA and Senior Service College Fellowship (leadership training program for civilian leaders in the military) programs as well as in the Doctor of Business Administration program at Lawrence Tech. He is also the Director of the Center for Global Leadership at Lawrence Tech. Dr. Marx has also taught Economics, Leadership, and Strategic Planning at Temple University, University of Detroit-Mercy, and Wayne State University. He has published a book and over 60 articles on leadership, planning and economics. 